\title{
WERE MUSCOVY AND CASTILE THE FIRST FISCAL-MILITARY STATES?
}

In this article Chester Dunning examines recent scholarship about John Brewer's model of the development of the early modern "fiscal-military“ state and the possibility of applying Brewer's model to sixteenth-century Russia and Castile (Spain). He concludes that Muscovy and Castile were probably the first "fiscal-military" states.

Keywords: John Brewer's model; 16th century; kingdom of Castile; Muscovy.

В данной статье Честер Даннинг рассматривает недавние исследования, посвященные модели развития «фискально-военного» государства Нового времени, созданной Джоном Брюэром, а также возможность приложения модели Брюэра к России XVI в. и Кастилии (Испания). Он делает вывод о том, что Московское государство и Кастилия, возможно, были первыми «фискально-военными» государствами.

Ключевые слова: модель Джона Бревера; XVI век; королевство Кастилия; Московия.

During the past twenty-five years, the concept of the "fiscal-military" state has taken firm root in historiography as an alternative to "absolutism." Many scholars have jettisoned the fuzzy and shopworn term "absolutism" in search of a more useful framework for comparative study of the development of early modern European states - the acceleration of expenditures, coercive taxation, and the build-up of powerful bureaucracy, logistical infrastructure, and military forces in light of the gunpowder revolution. The term "fiscal-military" state was coined by John Brewer in The Sinews of Power (1989) and applied to England's emergence as a Great Power at the end of the $17^{\text {th }}$ and beginning of the $18^{\text {th }}$ century [Brewer, p. xvii]. Nevertheless, Brewer's model is not exclusively Anglo-centric. In 1992 Nicholas Henshall suggested that Brewer's concept of the fiscal-military state was a viable alternative to the meaningless term "absolutism." He pointed out that by the late twentieth century "absolutism" was being defined in a way 180 degrees opposite from its original meaning. Scholars using the term have moved away from an image of powerful monarchs ruling by coercion to one of deep cooperation between court and elites, between center and periphery [Henshall, p. 2-3]. In 2001 Jan Glete fleshed out the components 
of early modern fiscal-military states and compared their successes and failures [Glete]. Among historians of early modern Europe the term fiscalmilitary state quickly caught on, indeed caught fire - due primarily to the weakness of "absolutism" as an explanatory framework. Many articles and essays have examined the development of early modern Spain, England, Brandenburg-Prussia, France, the Dutch Republic, Portugal, and even countries outside of Europe within the framework of the fiscal-military state [Brewer, Hellmuth; Simms, p. 79-100; Monad, p. 245, 322; Swann, p. 151-153; Edling, p. 48; Tengenu].

The concept of the fiscal-military state promises to be a useful tool for the comparative study of early modern European state formation, the military (gunpowder) revolution and its impact, and the origins of modern state structures. It also promises to help explain the birth and growth of "leviathan-states" in early modern Europe far better than the outdated term "absolutism" has done. A comprehensive definition of fiscalmilitary state is still in the process of formation, but it must of course begin with its relationship to the military revolution. The desire for conquest and expansion (or simply the need for stronger territorial defenses) had a profound effect throughout Europe. In most cases, the response of governments to the astronomically expensive military revolution and increasingly lethal geopolitical rivalries was to create stronger central administrative structures designed specifically to impose and collect higher taxes and to administer larger and increasingly professional military forces. As a result, state power grew enormously during the early modern period even as many European economies suffered from predatory taxes and increasing government interference. Fiscal-military states developed larger and more sophisticated centralized bureaucracies that were independent of traditional elites and were staffed by newly emerging professional bureaucrats and military personnel. Thus, the fiscal-military state was closely associated with innovation as well as increasing specialization and professionalization. Nevertheless, in mobilizing national resources and creating centralized power structures, kings and their ministers did not, as long thought, simply overawe and subjugate old elites, regional administrators, and local governments. Instead, fiscal-military states were characterized by cooperation between central and local governments and by an alliance between rulers and co-opted aristocrats who, far from resisting, were strongly attracted by the prospect of receiving prestigious and lucrative positions within the growing royal administration, its large military forces, or (in many cases) its expanding empire [Glete, p. 2, 7].

Although all fiscal-military states shared important basic characteristics, there were many variations due to such things as cultural differences, unique economic circumstances, pre-existing institutions and patterns of taxation, and relative levels of bureaucratic efficiency and comfort with innovation. Especially significant in determining the precise shape of each fiscal-military state was timing [Ertman, p. 1-34, 317-324]. All of them interfered with their domestic economies; but the ebb and flow of international pressures, 
relative access to new technologies, and different stages of economic development (and availability of credit) help explain many of the variations among fiscal-military states and their infrastructures. Some fiscal-military states developed very rapidly while others were comparatively slow to adopt the coercive techniques necessary for greatly increased revenue extraction and the creation of new institutions and military forces needed to meet the challenges of the military revolution.

The formation of the earliest fiscal-military states essentially predates capitalism, and those states tended to adopt extremely coercive methods for pulling revenue from their domestic economies without any real concern about the impact of their actions. Not surprisingly, such predatory practices often provoked fiscal crises and slowed down the development of capitalism [Henshall, p. 1-5]. Fiscal-military states that formed later tended to fare better, learning important lessons from the mistakes of the pioneers. Later fiscal-military states were often capable of mobilizing national resources without causing serious damage to the overall economy. Strategic planning and the use of well-trained professional bureaucrats yielded more reliable revenue streams and reduced destructive short-term expedients. More competent and effective administration also paid off on the battlefield and at sea [Glete, p. 142].

Spain - or, more precisely, the kingdom of Castile - has been plausibly identified as the first fiscal-military state [Rogers; Monad; Glete]. Long before the military revolution, Castile was already a highly militarized crusader state located on the frontier of Christendom and locked in a struggle to "reconquer" territory previously lost to Islam. That medieval experience greatly increased the power of the Castilian state and its rulers. By the beginning of the early modem period, the king of Castile was the absolute master of his realm where he wielded enormous power over his subjects, the economy, and even the church that neighboring monarchs could not imagine for themselves. Organized for ambitious military expansion in the name of God and king, Castile's bureaucratic administration and fiscal system contributed greatly to the enhancement of state power [Laredo Quesada, p. 177-196; Gelabert, p. 201-238]. War and the maintenance of military forces typically accounted for about half of Castile's annual expenditures [Rogers, p. 6; Thompson, p. 274-283, 290-291]. To pay those bills the Castilian bureaucracy used extremely coercive means of resource extraction that seriously harmed the country's economy, slowed down the growth of capitalism, and periodically contributed to fiscal crises that led to even more destructive short-term revenue producing expedients. Castile was chronically short of funds and often desperate to find the huge sums necessary to carry out its ambitious imperial agenda. Nevertheless, its early successes and the rapid growth of the Spanish empire worked against needed reform and promoted arrogance and bureaucratic inertia that ended up helping to ossify the economy, the state, and the empire [Glete, p. 100].

Castile's military expansion was not primarily motivated by profit. It was instead a sacred mission of the state carried out by aristocratic 
warriors. The level of cooperation between the Castilian government and national, regional, and local elites was very high, and taxes were imposed and collected without any meaningful consultation with the taxpayers. The king of Castile could also count on the strong support of the church as his empire expanded, and his powers over the church within his domain were very great. Such pronounced secular dominance was due in part to the king's decision not to staff his bureaucracy with church-trained administrators and the fact that the language of his court and bureaucracy (Castilian) was different from the language of the church (Latin) [Ruiz, p. 29-34, $147-148,154]$. Castile provides us with a very interesting case study of an early fiscal-military state. Were there any other similar pioneering fiscalmilitary states? The answer is a resounding yes! In many ways Muscovy was remarkably similar to Castile, something previously noted by several scholars [Billington, p. 69-71; Yanov, p. 7; Downing, p. 64].

I was the first historian to apply the term fiscal-military state to early modern Russia [Dunning, 1998, p. 119-131; idem, 1999, p. 136-137]. In my book, Russia's First Civil War: The Time of Troubles and the Founding of the Romanov Dynasty (2001), I described Russia in the sixteenth century as a somewhat primitive but highly effective version of the fiscal-military state [Dunning, 2001, p. 11, 19-21, 27-29, 34, 45-46, 48, 73, 462- 463, 476]. Influenced by Jan Glete, in 2004 James Cracraft published The Petrine Revolution in Russian Culture in which he used the term fiscal-military state to refer to the powerful military and bureaucratic system built up by Peter the Great - a more rational and efficient system of central command and control, taxation, recruitment, training, and supply [Cracraft]. In 2006 I coauthored an article with Stephen Smith titled "Moving beyond Absolutism: Was Early Modern Russia a Fiscal-Military State?” The article explores the bankruptcy of the terms "absolutism" and "autocracy" as explanatory frameworks for the study of early modern Europe and Russia, and it argues in favor of regarding Muscovy as one of the earliest fiscal-military states [Dunning, Smith, p. 19-43].

Several other scholars, including Brian Davies, Sergei Bogatyrev, and David Goldfrank, have made use of the concept of the fiscal-military state in writing about Muscovy. In 2007 Christoph Witzenrath published Cossacks and the Russian Empire, 1598-1725, in which he made sophisticated use of the term fiscal-military state in discussing Russia in the seventeenth century [Witzenrath]. In 2009 the Hungarian scholar Endre Sashalmi published a thoughtful essay titled "Russia as a Fiscal-Military and CompositeDynastic State, 1654-1725." Sashalmi acknowledged that the fiscal-military state is a highly plausible model for the study of early modern Russia, but he rejected Dunning's idea that Muscovy became a fiscal-military state in the $16^{\text {th }}$ century. For Sashalmi, the key to the emergence of a fiscal-military state was the creation of large and permanent armed forces, an increase in the number of administrative personnel, and increased taxes and government activity in order to finance those expenses. Sashalmi criticized Cracraft for focusing only on Peter the Great and the early $18^{\text {th }}$ century. 
Instead, he pointed to the Thirteen Years' War (1654-1667) as the real point of origin of Russia's fiscal-military state, referring to the build-up of the Russian bureaucracy and military forces during the long, exhausting war with Poland-Lithuania. Sashalmi also emphasized the relationship between the growth of the concept of the state in the second half of the seventeenth century and the actual growth of Russia's state apparatus and its increasing bureaucratization [Sashalmi, 2009b; 2009a, p. 131-147].

In 2009 Christopher Storrs published a collection of essays about fiscal-military states in the eighteenth century. Janet Hartley contributed an interesting essay, "Russia as a Fiscal-Military State, 1689-1825." Hartley emphasizes the fact that Russia was almost constantly at war in the eighteenth century and was essentially a garrison state and a fiscalmilitary state. Nevertheless, she is somewhat hesitant about using the term fiscal-military state to describe eighteenth-century Russia because much of Russian society remained unmilitarized and Russia's fiscal and banking structures (as well as its industrialization) lagged far behind the West. In other words, Hartley regards Russia not so much as a strong fiscal-military state as somehow managing to muddle through as a Great Power and huge empire [Hartley, p. 125-146]. In my opinion, Hartley does not focus enough attention on serfdom as the fuel for Russia's successful fiscal-military state, and she appears to misunderstand the relationship between increased local autonomy and the emergence of a powerful fiscal-military state (which is based on cooperation and devolution of authority) [Bogatyrev, p. 59-127]. For the past twenty-five years Brian Davies has been demonstrating the importance of the period leading up to Peter's reign in the development of Russia's military forces and administrative competence [Davies, 1992, p. 481-501; Idem, 2004]. Davies is also a leading expert on warfare in early modern Eastern Europe. In his recent book, Warfare in Eastern Europe, 1500-1800, Davies refers to the model of the fiscal-military state as a "prevailing paradigm" and calls for a more precise definition of the term [Davies, 2012; 2011].

In my view, Muscovy qualifies as a fiscal-military state by the sixteenth century. There is no need to wait until the eighteenth century. Marshall Poe has convincingly demonstrated that it was the sixteenth century that saw the development of key bureaucratic institutions, taxation, and warmaking ability in Muscovy [Poe, 1996, p. 608-618; 1998, p. 247-273]. At a conference I attended on "War and Warfare in Northern Europe, 15501721," held in early 2013 at the University of Aberdeen, historians of early modern Russia, Poland-Lithuania, Germany, Sweden, Scotland, England, and France welcomed the model of the fiscal-military state as a useful tool for the comparative study of early modern Europe. In The Northern Wars: War, State, and Society in Northeastern Europe, 1558-1721 (2000), the sponsor of the Aberdeen symposium, Robert I. Frost, drew attention to Russia's increasing momentum in the late sixteenth century. He correctly regarded Russia's Time of Troubles at the beginning of the seventeenth century as a powerful brake suddenly applied to that momentum [Frost]. 
The Time of Troubles definitely interrupted the formation of Russia's fiscal-military state. Far from slowing down its development, however, the Troubles actually accelerated the growth of state power, bureaucracy, and coercion that produced the rapid expansion of the Russian empire in the seventeenth century and its emergence as a Great Power by the early eighteenth century [Dunning, 2001, p. 443-480].

The model of the fiscal-military state promises to help us better understand some important aspects of early modern Russian history. It cannot explain why Castile managed to produce Don Quixote and Muscovy did not, but it can help explain why the promising economic development of both countries collapsed during the reigns of Philip II and Ivan the Terrible.

Billington J. The Icon and the Axe: An Interpretive History of Russian Culture. New York : Knopf, 1966. 880 p.

Bogatyrev S. Localism and Integration of Muscovy // Russia Takes Shape: Patterns of Integration from the Middle Ages to the Present / ed. S. Bogatyrev. Helsinki : Academy of Sciences and Finnish Letters, 2004. P. 59-127.

Brewer J. The Sinews of Power: War, Money and the English State, 1688-1783. New York : Knopf, 1989. 289 p.

Brewer J., Hellmuth E. Rethinking Leviathan: The Eighteenth-Century State in Britain and Germany / ed. J. Brewer, E. Hellmuth. New York : Oxford Univ. Press, 1999. 412 p.

Cracraft J. The Petrine Revolution in Russian Culture. Cambridge, MA : Belknap Press, 2004. 576 p.

Davies B. Empire and Military Revolution in Eastern Europe: Russia's Turkish Wars in the Eighteenth Century. London : Continuum International Publishing Group, 2011. 375 p. Davies B. State Power and Community in Early Modern Russia: The Case of Kozlov, 1635-1649. London : Palgrave Macmillan, 2004. 308 p.

Davies B. Village into Garrison: The Militarized Peasant Communities of Southern Muscovy // The Russian Review 51. No. 3. 1992. P. 481-501.

Davies B. Warfare in Eastern Europe, 1500-1800. Leiden : Brill, 2012. 364 p.

Downing B. The Military Revolution and Political Change. Princeton : Princeton Univ. Press, 1992. 308 p.

Dunning Ch. The Preconditions of Modern Russia's First Civil War // Russian History 25. Nos. 1-2. 1998. P. 119-131.

Dunning Ch. The Legacy of Russia's First Civil War and the Time of Troubles // Forschungen zur osteuropäischen Geschichte 56. 1999. P. 132-155.

Dunning Ch., S. L. Russia's First Civil War: The Time of Troubles and the Founding of the Romanov Dynasty. University Park : Penn State Press, 2001. 657 p.

Dunning Ch., Smith N. S. Moving beyond Absolutism: Was Early Modern Russia a 'Fiscal-Military' State? // Russian History 33. No. 1. 2006. P. 19-43.

Edling M. M. A Revolution in Favor of Government: Origins of the U. S. Constitution and the Making of the American State. New York: Oxford Univ. Press, 2003. 336 p.

Ertman Th. Birth of Leviathan: Building States and Regimes in Medieval and Early Modern Europe. Cambridge : Cambridge Univ. Press, 1997. 380 p.

Frost R. I. The Northern Wars: War, State, and Society in Northeastern Europe, 15581721. Harlow, England : Longman, 2000. 416 p.

Gelabert J. Castile, 1504-1808 // The Rise of the Fiscal-State in Europe, c.1200-1815 / ed. B. Richard. Oxford : Oxford Univ. Press, 1999. P. 201-238.

Glete J. War and the state in early modern Europe: Spain, the Dutch Republic and Sweden as Fiscal-Military States. London : Routledge, 2001. 277 p.

Hartley J. Russia as a Fiscal-Military State, 1689-1825 The Fiscal-Military State in Eighteenth-Century Europe: Essays in Honor of P. G. M. Dickson / ed. C. Storrs. Burlington. VT : Ashgate, 2009. P. 125-146.

Henshall N. The Myth of Absolutism: Change \& Continuity in Early Modern European Monarchy. London : Longman,1992. 245 p. [Khenshell N. Mif absoliutizma: Peremeny 
i preemstvennost' v razvitii zapadno-evropeiskikh monarkhii rannego Novogo vremeni. SPb. : Aleteiia, 2003. $271 \mathrm{s.}$ ]

Laredo Q. M. A. Castile in the Middle Ages. The Rise of the Fiscal-State in Europe, c.1200-1815 / ed. R. Bonney. Oxford : Oxford Univ. Press, 1999. P. 177-196.

Monad P. K. The Power of Kings: Monarchy and Religion in Europe, 1589-1715. New Haven : Yale Univ. Press, 1999. 422 p.

Poe M. The Consequences of the Military Revolution in Muscovy in Comparative Perspective // Comparative Studies in Society and History 38. No. 4. 1996. P. 608-618.

Poe M. The Military Revolution, Administrative Development, and Cultural Change in Early Modern Russia // Journal of Early Modern History 2. No. 3. 1998. P. 247-273.

Rogers $C$. The Military Revolution Debate: Readings on the Military Transformation of Early Modern Europe / ed. C. Rogers. Westview Press, 1995. 400 p.

Ruiz T. F. From Heaven to Earth: The Reordering of Castilian Society, 1150-1350.

Princeton : Princeton Univ. Press, 2004. 240 p.

Sashalmi E. God is High Up. The Tsar is Far Away. The Nature of Polity and Political Culture in Seventeenth-Century Russia: A Comparative View Empowering Interactions. Political Cultures and the Emergence of the State in Europe, 1300-1900 / eds. W. Blockmans, A. Holenstein, I. Mathieu. Burlington, VT : Ashgate, 2009a. P. 131-147.

Sashalmi E. Russia as a Fiscal-Military and a Composite-Dynastic State, 1654-1725 // Gosudarstvo i natsiia v Rossii i Tsentralno-vostochnoi Evrope [State and Nation in Russia and Central East Europe] / ed. G. Szvak. Budapest : Russica Pannonica, 2009b.

Simms B. Reform in Britain and Prussia, 1797-1815: (Confessional) Fiscal-Military State and Military-Agrarian Complex // Reform in Great Britain and Germany 1750-1850 / eds. T. C. W. Blanning, P. Wende. Oxford : Oxford Univ. Press. 1999. P. 79-100.

Swann J. The State and political culture // Old Regime France: 1648-1788 / ed. W. Doyle. Oxford : Oxford Univ. Press, 2001. P. 151-153.

Tengenu T. The Evolution of Ethiopian Absolutism: The Genesis and the Making of the Fiscal-Military State, 1696-1913. Uppsala : Uppsala Univ. Press, 1998. 286 p.

Thompson A. A. Money, Money, and Yet More Money: Finance, Fiscal State and the Military Revolution // The Military Revolution Debate: Readings on the Military Transformation of Early Modern Europe / ed. C. Rogers. Westview Press, 1995. P. 273-298.

Witzenrath C. Cossacks and the Russian Empire, 1598-1725: Manipulation, Rebellion and Expansion into Siberia. London : Routledge, 2007. 282 p.

Yanov A. The Origins of Autocracy: Ivan the Terrible in Russian History. Berkeley: Univ. of California Press, 1981.339 p.

The article was submitted on 28.12.2013

Честер Даннинг, проф. США

Техасский университет c-dunning@tamu.edu

\author{
Chester Dunning, prof. \\ USA \\ Texas University \\ c-dunning@tamu.edu
}

